\title{
Identification of the Oligocene-Miocene boundary in the Central Iran Basin (Qom Formation): calcareous nannofossil evidences
}

\author{
Mohammad PARANDAVAR ${ }^{1}$ and Fatemeh HADAVI ${ }^{1, *}$ \\ 1 Ferdowsi University of Mashhad, Department of Geology, Faculty of Sciences, Mashhad, Iran
}

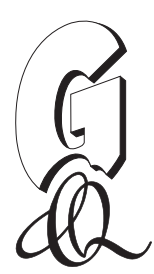

Parandavar, M., Hadavi, F., 2019. Identification of the Oligocene-Miocene boundary in the Central Iran Basin (Qom Formation): calcareous nannofossil evidences. Geological Quarterly, 63 (2): 215-229, doi: 10.7306/gq.1464

Associate Editor - Wojciech Granoszewski

A diverse Late Oligocene to Early Miocene calcareous nannofossil assemblage was examined from the Qom Formation in the Central Iran Basin, and the Oligocene-Miocene boundary was identified based on the quantitative analysis of the assemblages in 303 smear slides. Eleven well-established calcareous nannofossil bio-events are delineated in the Upper Oligocene through Lower Miocene. The results clearly show that the Highest Occurrence (HO) of Sphenolithus delphix is the closest bio-event to the boundary as traditionally delineated on the lithostratigraphic criteria, and provides a distinct biohorizon below it. The Lowest Occurrence (LO) of the species Discoaster druggii is the oldest Miocene bio-event that is observed shortly after the $\mathrm{HO}$ of $S$. delphix, showing that calcareous nannofossils are well suited for approximating the Oligocene-Miocene boundary in the Qom Formation. The Oligocene-Miocene boundary is placed in the upper part of Sub-member "c1" in all three sections studied here and it is traceable throughout the Central Iran Basin, which makes a potentially reliable marker horizon for sequence stratigraphic and hydrocarbon studies in the area

Key words: Oligocene-Miocene boundary, calcareous nannofossils, biohorizons, Central Iran Basin, Qom Formation, "c1" Sub-member.

\section{INTRODUCTION}

Identification of the boundary between the Oligocene and Miocene has been often difficult in geological records (Shackleton et al., 2000). Berggren (1969) defined an age of 22.5 Ma for the Oligocene-Miocene boundary and demonstrated that it could be correlated approximately to the magnetochrone C6An. Then, Berggren et al. (1985) reviewed the boundary criteria and determined an age of 23.8 Ma for it based on the last appearance of the nannofossil species of Reticulofenestra bisecta, Reticulofenestra scrippsae and Cyclicargolithus abisectus. Steininger et al. (1997) assigned an age of $23.8 \mathrm{Ma}$ to the boundary placed at the base of the $\mathrm{C} 6 \mathrm{Cn} .2 \mathrm{n}$ magnetozone to define the GSSP for the base of the Neogene. Lourens et al. (2004), Palike et al. (2006) and Gradstein et al. (2012) in their new synthesis have proposed an age of 23.03 Ma for the base of the C6Cn.2n magnetozone.

Several climatic changes have been reported at the Oligocene-Miocene transition from various locations in the Tethyan and equatorial realms (Zachos et al., 2001; Allen and

\footnotetext{
* Corresponding author, e-mail: fhadavi@um.ac.ir Received: February 24, 2018; accepted: November 9, 2019; first published online: May 17, 2019
}

Armstrong, 2008; Beddow et al., 2016). The main cause for such environmental changes is massive tectonic displacements which led to reduction in atmospheric pCO2 (Pagani et al., 1999; Pearson and Palmer, 2000), and changes in palaeoclimate and palaeoenvironmental conditions (Zachos et al., 2001).

The Arabia-Eurasia collision and the closure of the Tethys ocean gateway is one of the global tectonic events that span from the Late Eocene to Miocene (Allen and Armstrong, 2008; Sadr, 2017). Previous studies based on the palaeoecology and palaeoclimatology of the Oligocene to Miocene transition suggested that fluctuations in global ice volume and eustatic sea level, and temperature variations during glacial or interglacial periods have resulted in the biological-environmental crises (Miller et al., 1991; Zachos et al., 2001; Billups et al., 2002). Moreover, multiple shifts in the value of ${ }^{18} \mathrm{O}$ and ${ }^{13} \mathrm{C}$ isotopes were reported during this interval from various sites (Zachos et al., 2001; Pekar et al., 2002; Wade and Palike, 2004; Beddow et al., 2016). They are referred to as Oi- and Mi-events. These changes and the global cooling trends have led to the biological crisis in the biota assemblages of the Late Oligocene to Miocene (as shown for instance in the Oligocene-Early Miocene range charts in Perch-Nielsen, 1985). Differences in the occurrences of these biological events (recorded or not at different sites), and more specifically differences in their chronostratigraphic position from one site to another, have resulted in problems in precise delineation of the Oligocene-Miocene boundary. Because of these problems, identification and introduction of major bio-events, and chronostratigraphic dating of the 
Oligocene-Miocene boundary have often been considered as a challenge.

An accurate interpretation of stage boundaries is very importance for stratigraphy (including sequence stratigraphy) which is the main tool for hydrocarbon exploration studies (e.g., Catuneanu, 2013). This, however, can only be facilitated by having detailed and valid biostratigraphic information in the area targeted for hydrocarbon exploration. Therefore, this study attempts to contribute to determining the Oligocene-Miocene (Chattian/Aquitanian) boundary through a detailed study of calcareous nannofossil biohorizons at three outcrop sections in the Central Iran Basin.

\section{STRATIGRAPHIC SETTING}

The Qom Basin in the Central Iran Zone (CIZ) (Fig. 1A) formed during middle Alpine orogenic time (Paleogene to Early Miocene; Berberian and King, 1981). During the Eocene orogeny, extensive volcanism occurred in the $\mathrm{CIZ}$ in a NW-SE-trending area known in the literature of Iranian geology as the Orumia-Dokhtar Magmatic Arc (e.g., Berberian and King, 1981; Aghanabati, 2004; Shahabpour, 2007). The subsequent Oligocene-Miocene marine transgression resulted in the spreading of marine carbonate sequences along the NW margin of the Arabian plate (Zagros Basin; Asmari Formation) and the SSW margin of the Iranian plate (Qom Basin; Qom Formation) (Dozy, 1944, 1955; Bozorgnia, 1966; Berberian and King, 1981; Aghanabati, 2004; Fig. 1B).

Following petroleum discovery in the Serajeh and Alborz fields (Central Iran Basin) in 1934 (Mostofi and Gansser, 1957;
Abaie et al., 1964; Rosenberg, 1975), the Qom Formation became a focus of biostratigraphic, palaeogeographic, palaeoecologic, sequence stratigraphic, microfacies, and tectonic studies (e.g., Reuter et al., 2007; Daneshian and Ramezani Dana, 2007; Hadavi et al., 2010; Yazdi-Moghadam, 2011; Mohammadi et al., 2013; Daneshian and Ghanbari, 2017; Daneshian and Ramezani Dana, 2017; Parandavar and Hadavi, 2017).

The Qom Formation is widely distributed in the Qom backarc, arc, and fore-arc basins (Reuter et al., 2007; Fig. 2A). The first marine transgression of the Qom Sea can be traced back to the Early Oligocene in the fore-arc basin and to the Late Oligocene in the back-arc basin (Reuter et al., 2007; Yazdi-Moghadam, 2011). Because of the various facies present in the Qom Formation, no type section has been introduced for it yet, although the Qom area is defined as its "type area" (Stocklin and Setudehnia, 1991; Aghanabati, 2004). In the type area, the Qom Formation in ascending stratigraphic order is divided into six members. They are: $a$ - sandy limestones, $b-$ silty limestones with alternations of silty marlstone, $\mathrm{c}$ - alternating marlstones and limestones, d - evaporites, e - green marlstones, f - reefal limestones (Furrer and Soder, 1955; Soder, 1956; Abaie et al., 1964; Stocklin and Setudehnia, 1991) (Fig. 3). The c-Member is subdivided into four sub-members by Soder (1959), including: c1 - marlstones with intercalations of limestones, c2 - evaporites, c3 - shallow-water limestones, c4 - green marlstones. Reuter et al. (2007) have not subdivided the c-Member and used the term "c-Member" as a thickened interval of the Qom Formation. Outside of the type area (Qom), most of the mentioned members and sub-members are not present in the CIZ (Stocklin and Setudehnia, 1991; Aghanabati, 2004). Therefore, this study was focused on the Qom, Kashan and Garmsar areas where a complete Oligocene-Miocene suc-
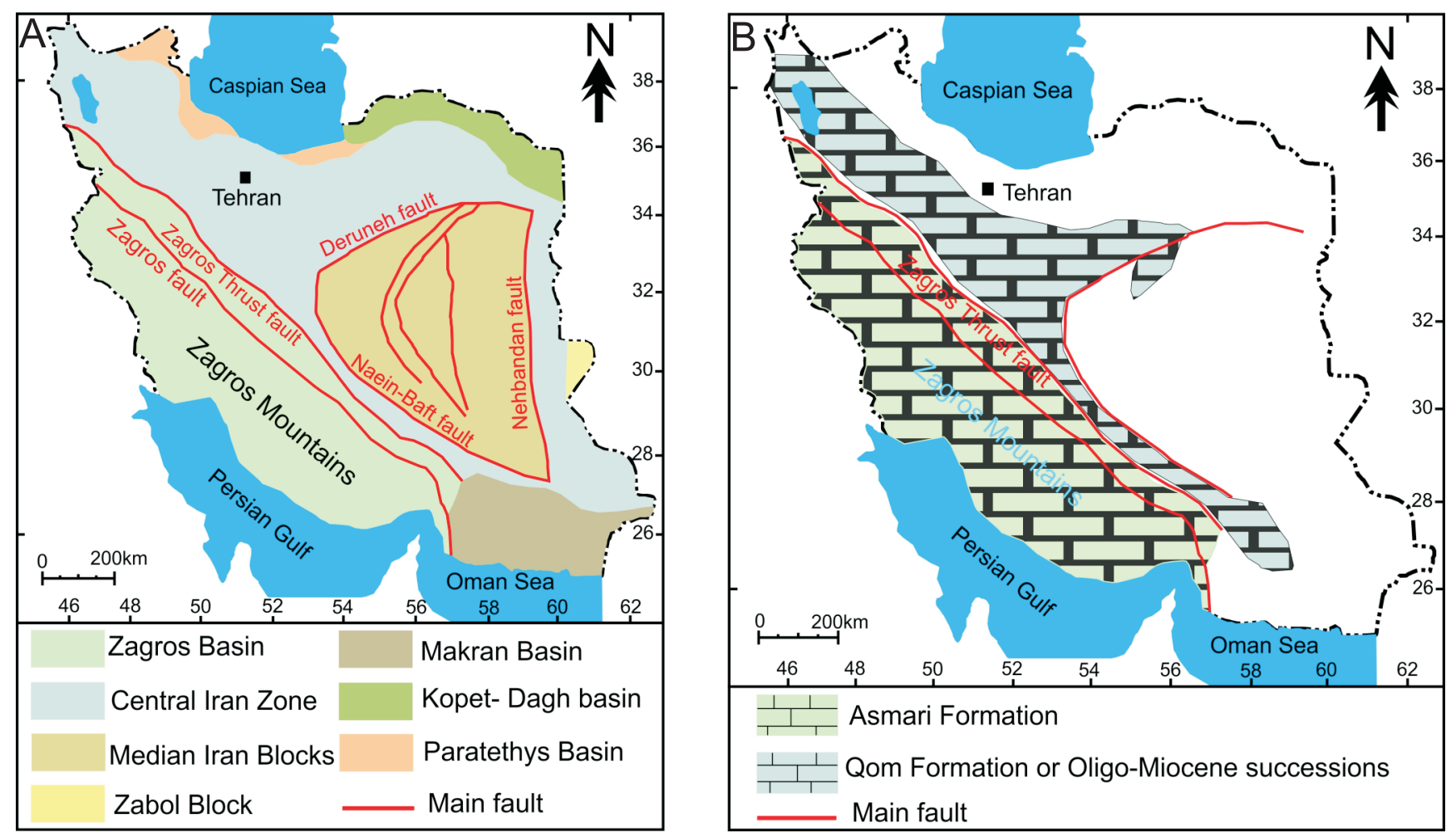

Fig. 1A - general map of Iran showing the sedimentary basins and structural zones (modified after Aghanabati, 2004); B - distribution of the Oligocene-Miocene marine carbonates of the Qom and Asmari formations in Central Iran Zone (CIZ) and Zagros Basin (modified after Berberian and King, 1981) 

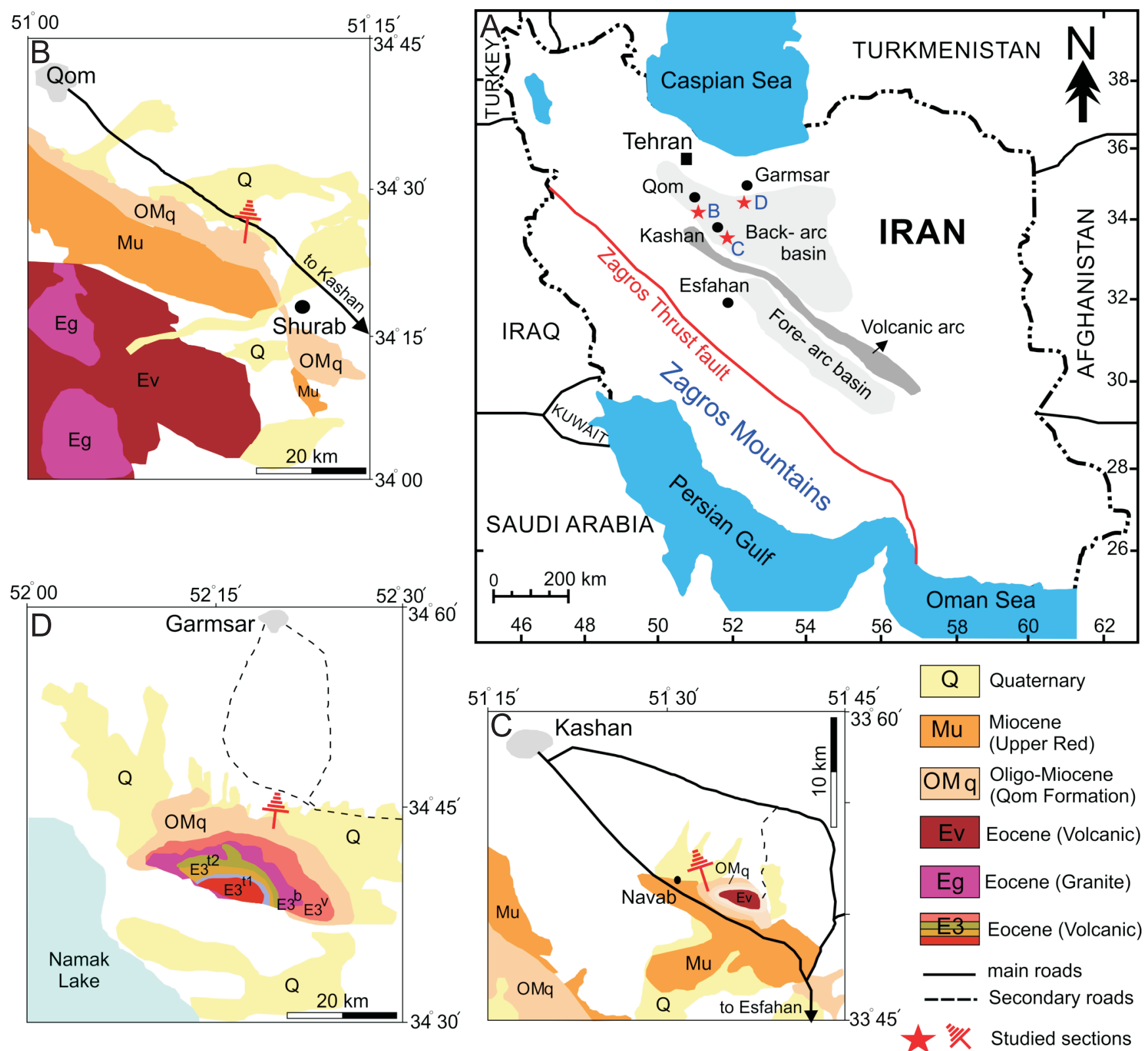

Fig. 2A - sedimentary basins of the Qom Formation: back-arc and fore-arc basins (modified after Reuter et al., 2007); red stars indicate location of the studied sections in the Qom Basin (back-arc basin) of Central Iran; B, C D - geological maps of the Shurab, Navab Anticline, and Siah-Kuh areas, showing location of the sections (modified after Emami, 1992; Khalatbari and Alavi, 1996)

cession of the Qom Formation was reported (Rahaghi, 1973, 1976, 1980; Reuter et al., 2007; Mohammadi et al., 2011, 2013; Parandavar, 2018). Previous biostratigraphic studies of the Qom Formation reached no comprehensive agreement on the chronostratigraphy of the Formation, in particular with regard to the placement of the Oligocene-Miocene boundary (Reuter et al., 2007; Yazdi-Moghadam, 2011).

\section{STUDY AREA}

The best outcrops of the Qom Formation are exposed in the type area, south-east of the Kashan, south of the Garmsar and around Qom. In the present study, three stratigraphic sections located at the Shurab (south of Qom), Navab Anticline (south- -east of Kashan) and Siah-Kuh (south of Garmsar) were measured and sampled in detail. In all three sections, the Oligocene to Miocene interval occurs below the red gypsiferous marlstones and/or gypsum successions of Sub-member "c2" and positioned within the green to grey marlstones of Sub-member "c1". Therefore, the Oligocene-Miocene interval does not show a clear change in lithology or sedimentological characteristics.

\section{SHURAB SECTION}

The Shurab section is the best outcrop of the Qom Formation in the type area, including all members of the Qom Formation, cropping out south of the city of Qom (Stoecklin, 1959), $\sim 35 \mathrm{~km}$ to the south of Qom within the Qom back-arc basin 
$\left(34^{\circ} 25^{\prime} \mathrm{N}, 51^{\circ} 08^{\prime} \mathrm{E}\right.$; Fig. $\left.2 \mathrm{~A}, \mathrm{~B}\right)$. The total thickness of this-section is $543 \mathrm{~m}$ and it exposes the "a" to "f" members of the Qom Formation. Detailed analysis of calcareous nannofossils was performed on Sub-member "c1" of the section (from sample No. 140 to sample No. 250). Lithologically, Sub-member "c1" consists of alternating green to grey marlstones and marly limestones which overly the dark brown silty limestones of the Member "b", and is overlain by the red gypsiferous marlstones and gypsum beds of Sub-member "c2" (see Fig. 4).

\section{NAVAB ANTICLINE SECTION}

The section ( $411 \mathrm{~m}$ thick) is located $25 \mathrm{~km}$ to the south-east of Kashan city (Qom back-arc basin) with the coordinates of $33^{\circ} 51^{\prime} \mathrm{N}, 51^{\circ} 38^{\prime} \mathrm{E}$ (Fig. 2C). The Qom Formation includes members "a" to " $f$ " in this section (Fig. 3). As in the Shurab section, this study focusses on Sub-member "c1" with a thickness of $63 \mathrm{~m}$ (from sample No. 85 to sample No. 225). The member consists of green to grey marlstones with alternation of argillaceous limestones; it overlies the thick-bedded silty-argillaceous limestones of Member " $b$ " and underlies the red gypsiferous marlstones of Sub-member "c2" (see Fig. 5).

\section{SIAH-KUH SECTION}

The Qom Formation is cropping out $\sim 40 \mathrm{~km}$ to the south of Garmsar city in the Siah-Kuh within the Qom back-arc basin $\left(34^{\circ} 43^{\prime} \mathrm{N}, 52^{\circ} 15^{\prime} \mathrm{E}\right.$; Fig. 2D). The total thickness of the Siah-Kuh section is $493 \mathrm{~m}$ and it exposes sub-members "c1" to " $\mathrm{f}$ " of the Qom Formation. The $48 \mathrm{~m}$ thick Sub-member "c1" (from sample No. 1 to sample No. 38) is studied here for calcareous nannofossil biostratigraphy. It consists of argillaceous limestones and green to grey marlstones. Sub-member "c1" rests unconformably on the red sandstones of the Lower Red Formation (LRF) and is conformably overlain by the red gypsiferous marlstones of Sub-member "c2" (Fig. 6).

\section{MATERIALS AND METHODS}

Throughout the studied outcrops, samples were collected with an average spacing of $50 \mathrm{~cm}$, although the sample resolution decreased to $20-30 \mathrm{~cm}$ in some intervals. A total of 303 samples were thus obtained from the marlstone and marly limestone succession of Sub-member "c1". They were prepared using the smear slide technique (Bown and Young, 1998). For each sample, $5 \mathrm{mg}$ of rock was weighed, dispersed in $0.5 \mathrm{ml}$ ( 10 drops) of distilled water, disaggregated with the sodium hexa-metaphosphate powder, and a few drops of the suspension were finally transferred on a glass slide. After drying the suspension on a heating plate, the slides and coverslips were mounted using Entellan glue. Slides were examined using a light microscope (Olympus BX53) at 1250X magnification. Images of coccoliths were taken using an Olympus DP73 camera.

Various calcareous nannofossil zonal schemes were established by Martini (1971), Okada and Bukry (1980), Varol (1998), Young (1998), Backman et al. (2012) and Agnini et al. (2014) for the Upper Oligocene to Lower Miocene at low and middle latitudes. The standard zonal scheme of Martini (1971; NP and NN zones) is used here. However, the zonal markers of Backman et al. (2012; CNM zones) and Agnini et al. (2014; $\mathrm{CNO}$ zones) were also considered. For the determination of calcareous nannofossil species, we adopted the taxonomy pro- posed by Aubry (1984, 1988, 1989, 1990), Perch-Nielsen (1985), Farinacci (1989), Varol (1998), Young (1998) and Howe (2016). The Highest Occurrences (HO) of Sphenolithus ciperoensis, Reticulofenestra bisecta, R. stavensis, Cyclicargolithus abisectus, Helicosphaera recta and Zygrhablithus bijugatus, the Lowest Occurrences (LO) of Triquetrorhabdulus carinatus, LO and HO of Sphenolithus delphix, and LO of Discoaster druggii, have been useful for a biozonal subdivision in the present study. The biohorizons used in this research are as follows: the Lowest Occurrence (LO), the Highest Occurrence (HO) and the Highest Common Occurrence (HCO) (Aubry, 2016).

Quantitative analysis was utilized to establish distribution patterns of selected calcareous nannofossil taxa. The abundance of selected species was determined by counting the number of specimens in a prefixed area of smear slides $\left(\mathrm{N} / \mathrm{mm}^{2}\right)$ following Backman and Shackleton (1983). The prefix area (total area of fields of view) was related to 50 Fields Of View (FOV). The results of counting analyses performed on Sub-member "c1" of the Qom Formation in Shurab, Navab Anticline and Siah-Kuh surface sections are shown in Figures 4-6.

\section{TAXONOMIC NOTES}

\section{Reticulofenestra bisecta}

(Hay, Mohler and Wade, 1966) Roth, 1970 1966

Basionym: Syracosphaera bisecta Hay, Mohler and Wade,

Variants: R. stavensis (Levin and Joerger, 1967) Varol, 1989; Dictyococcites scrippsae Bukry and Percival, 1971.

Two different taxonomic subdivisions have been used for $R$. bisecta according to nannotax database:

1. Specimens $<10 \mu \mathrm{m}=D$. scrippsae, specimens $>10 \mu \mathrm{m}=$ D. bisectus;

2. Specimens $<10 \mu \mathrm{m}=R$. bisecta, specimens $>10 \mu \mathrm{m}=$ $R$. stavensis.

The latter division is followed here. In the studied materials, the size of $R$. bisecta ranges from 7.6 to $8.4 \mu \mathrm{m}$, and of $R$. stavensis from 13.6 to $15.4 \mu \mathrm{m}$ (see Fig. 9).

\section{RESULTS}

\section{APPLICATION OF MARTINI (1971) BIOSTRATIGRAPHIC SCHEME AND ADDITIONAL BIO-EVENTS}

This study shows that the Zone NN1 of Martini (1971) is present in Sub-member "c1" of the Qom Formation. Following the literature (Martini, 1971; Perch-Nielsen, 1985), this biozone is defined as the $\mathrm{HO}$ of $H$. recta and/or S. ciperoensis to the LO of $D$. druggii. As this zone includes several bio-events which have been reported by various authors (Okada and Bukry, 1980; Perch-Nielsen, 1985; Backman et al., 2012; Agnini et al., 2014), Sub-member "c1" can be subdivided into smaller intervals by specific events (Figs. 4-6). Herein, in order to determine the Oligocene-Miocene boundary, we described the identified bio-events in our study area and compared them with the known bio-events from various sites. In the following, these are listed in the ascending stratigraphic order (see also Figs. 4-7). Microscopic photos of index calcareous nannofossil as well as of several synchronic taxa are provided in Figures 8 and 9 .

A: HO of Sphenolithus ciperoensis. HO of S. ciperoensis is used to define the base of zones NN1, CN1a and CNO6 (Martini, 1971; Okada and Bukry, 1980; Agnini et al., 2014) and 

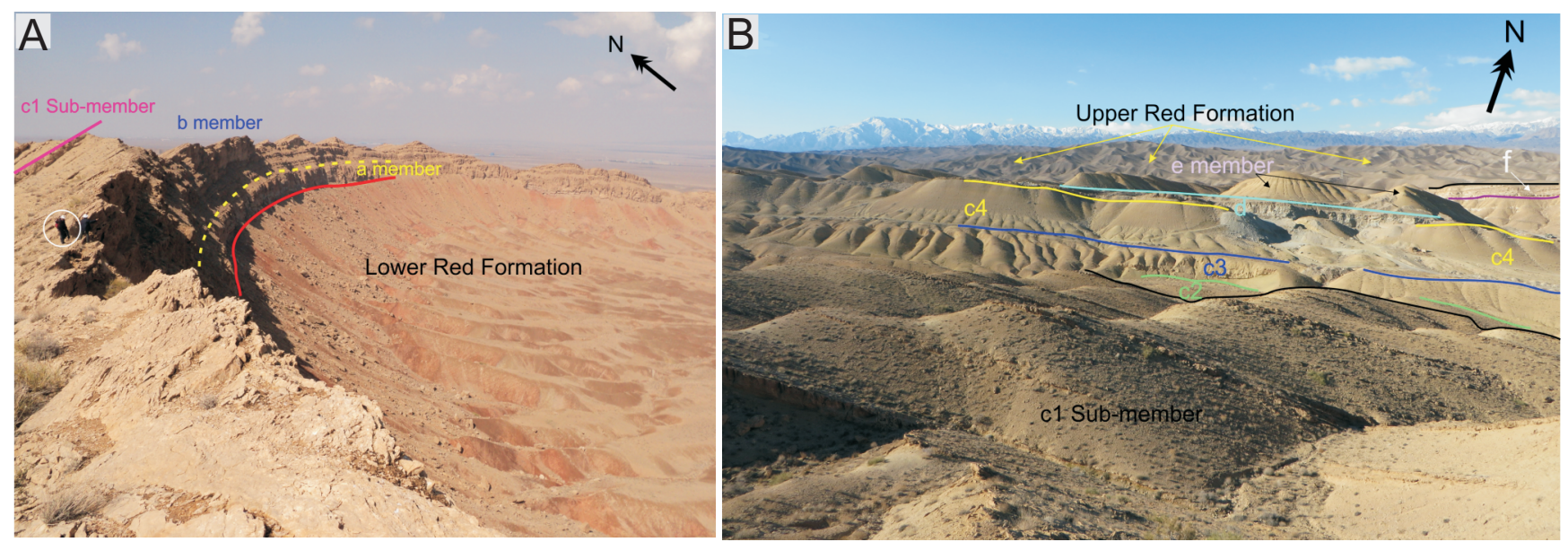

Fig. 3A - view of the lower part of the Qom Formation (sub-/members "a" to "c1") in the Navab Anticline section; the Qom Formation rests unconformably on the Lower Red Formation; person for scale (white circle); B - view of the upper parts of the formation consisting of sub-/members "c1" to " $f$ "; the Qom Formation underlies unconformably the Upper Red Formation

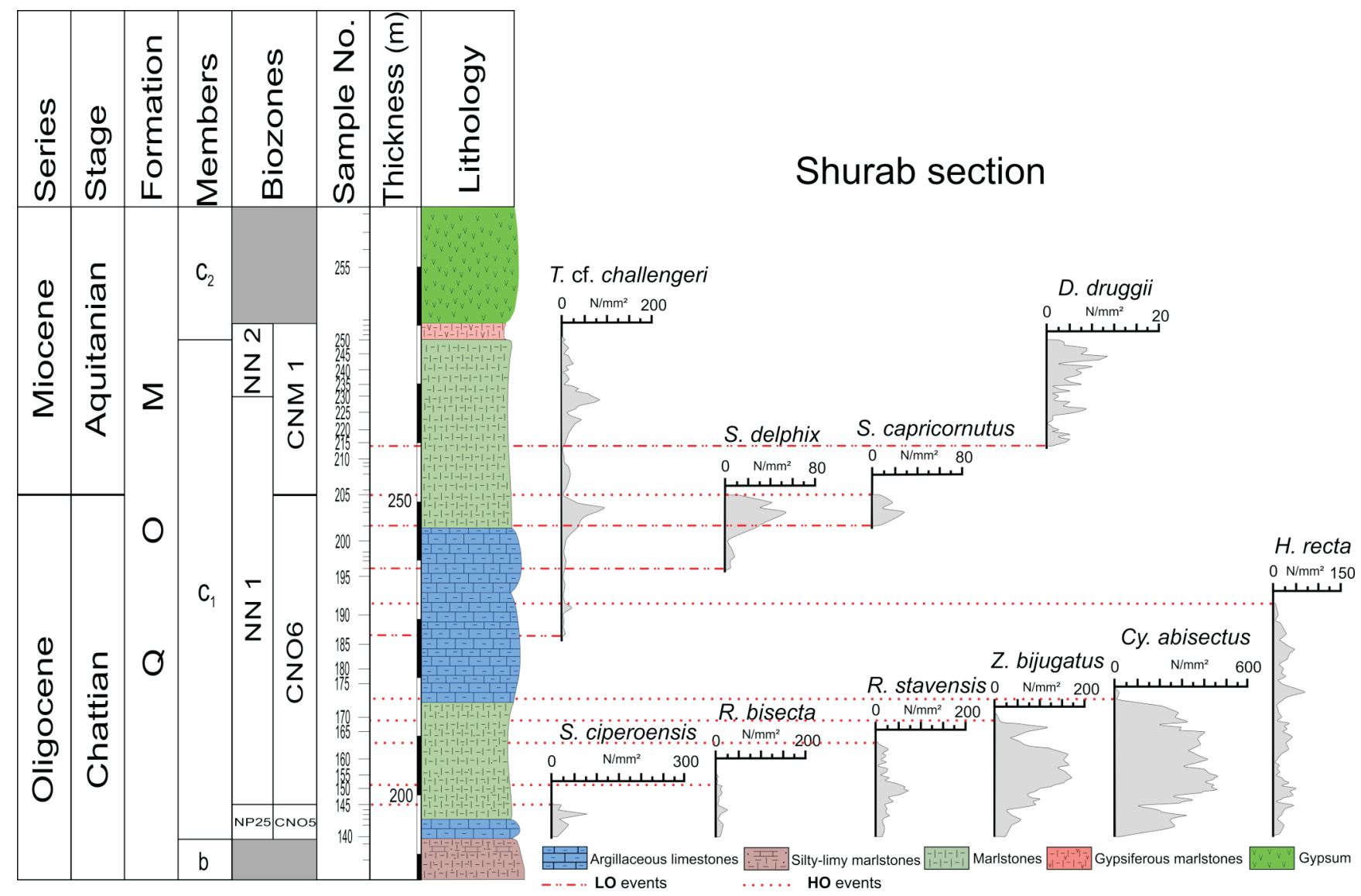

Fig. 4. Lithological characteristics of the Oligocene/Miocene interval of the Shurab section

Abundance patterns of selected species useful for the Upper Oligocene-Lower Miocene standard biozonation are shown (NP and NN - Martini, 1971; CNO - Agnini et al., 2014; CNM - Backman et al., 2012); the X-axis values represent the number of specimens in a prefixed area $\left(\mathrm{N} / \mathrm{mm}^{2}\right)$ related to $50 \mathrm{FOV}$; different dashed lines highlight the LO or HO of species; the light grey rectangles show unstudied intervals

it has been used to delineate the Oligocene-Miocene boundary in the past (Perch-Nielsen, 1985). Recent studies (e.g., Rio et al., 1990; Raffi et al., 2006; Backman et al., 2012; Agnini et al., 2014) have confirmed earlier ones that showed it to be an Oligocene bio-event. In the Shurab section, the bio-event is re- corded at $198 \mathrm{~m}$ (Fig. 4). It is placed at $114 \mathrm{~m}$ of Navab Anticline outcrops of Sub-member "c1" (Fig. 5). The event has not been observed in the Siah-Kuh section (Table 1). Therefore, the base of the zone cannot be correlated with other sections in the Qom Basin. 


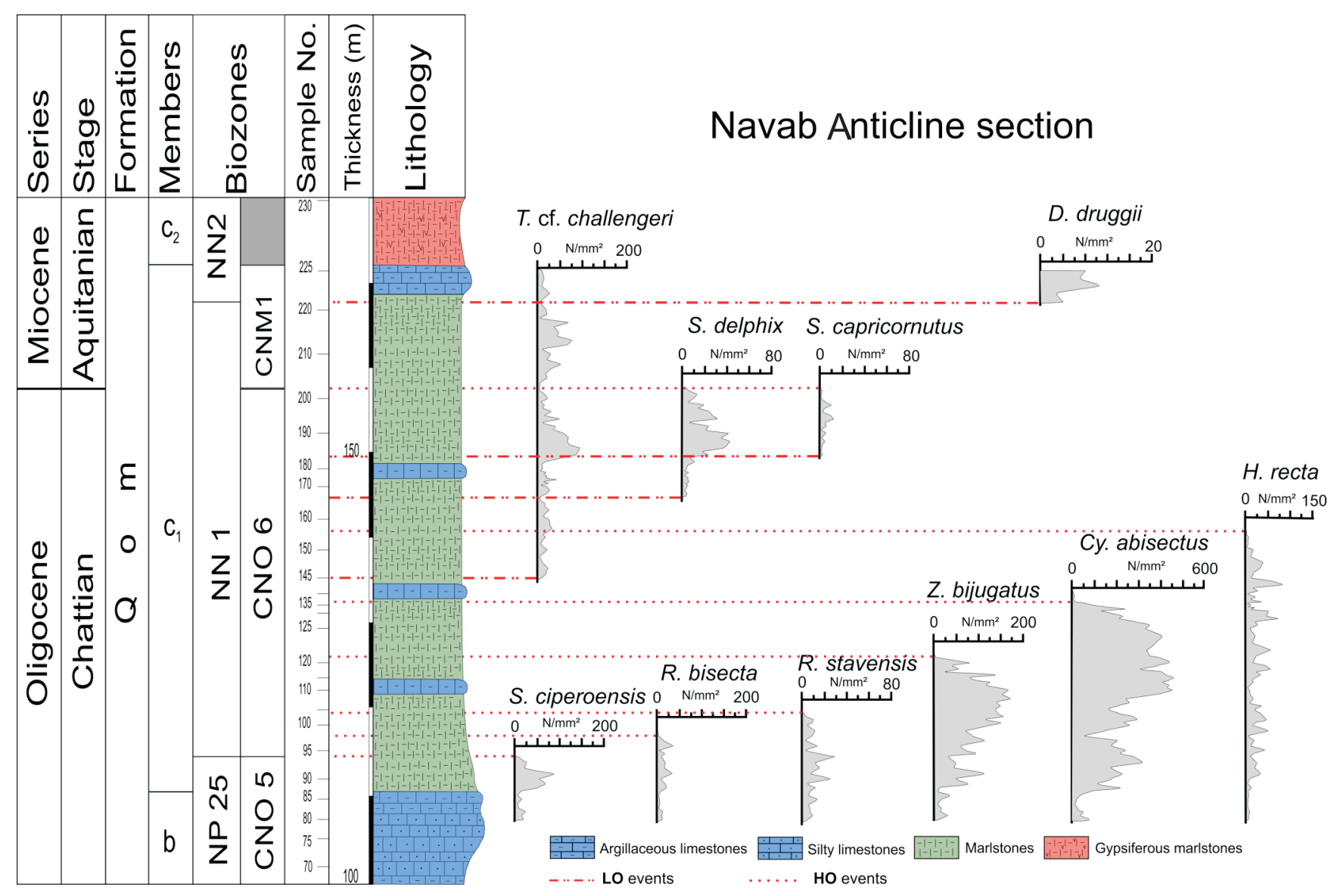

Fig. 5. Selected calcareous nannofossil abundance patterns from the Oligocene/Miocene interval of the Navab Anticline section

The standard biozonation of Martini (1971; NP and NN), Agnini et al. (2014; CNO) and Backman et al. (2012; CNM) are used in the present study; the X-axis values represent the number of specimens in a prefixed area $\left(\mathrm{N} / \mathrm{mm}^{2}\right)$ related to $50 \mathrm{FOV}$; dashed lines highlight the $\mathrm{LO}$ or $\mathrm{HO}$ of species; the light grey rectangles show unstudied interval

B: HO of Reticulofenestra bisecta. Okada and Bukry (1980) employed this biohorizon to define the lower boundary of Subzone CN1a. Agnini et al. (2014) assume that the LO of $R$. bisecta occurred at a level which is slightly younger than $S$. ciperoensis. In this study, sporadic occurrence of $R$. bisecta $(<10 \mu \mathrm{m})$ is observed above the $\mathrm{HO}$ of $\mathrm{S}$. ciperoensis and within Zone NN1 of Martini (1971) (Figs. 4-7 and Table 1).

C: $\mathrm{HO}$ of Reticulofenestra stavensis. The $\mathrm{HO}$ of $R$. stavensis is observed in all studied sections. The biohorizon occurs within Zone NN1 of Martini (1971) and above of the HO of S. ciperoensis (Figs. 4-7) in all sections. Varol (2017) employed this bio-event to define Subzone NN1a. The sample numbers and stratigraphic position of the bio-event are presented in Table 1 for all sections. Herein, this event has been recorded above the $\mathrm{HO}$ of $R$. bisecta (Figs. 4-6).

D: $\mathrm{HO}$ of Zygrhablithus bijugatus. This $\mathrm{HO}$ is similar to the bio-event reported by Varol (2017), which is used to define Subzone NN1b. In the present study, this biohorizon is recorded in the lower part of Zone NN1 of Martini (1971) and in the middle part of Sub-member "c1" (Figs. 4-6 and Table 1).

$\mathrm{E}$ : HCO of Cyclicargolithus abisectus. The species is common and abundant in the calcareous nannofossil assemblages of the studied sections. The HCO of large specimens of C. abisectus lies within Zone NN1 in all sections (Figs. 4-7 and Table 1), while, as yet, the Oligocene species (such as H. recta) can be seen in the calcareous nannofossil assemblages after the record of this bio-event (Figs. 4-6). Based on its distinct abundance patterns in Rio et al. (1990) and Olafsson (1992), the large form of $C$. abisectus $(>10 \mu \mathrm{m})$ is very rare in the Miocene and the $\mathrm{HO}$ of the taxon occurs in Zone NN7 of Martini (1971), but its highest abundant occurrence lies above of the LO of the S. ciperoensis bio-event in Zone NN1.

F: LO of Triquetrorhabdulus challengeri. Varol (2017) reported the bio-event within the Oligocene calcareous nannofossil assemblages and used the LO of $T$. challengeri to define Subzone NN1c. In this study, we were not able to determine confidently this form in the studied sections. However, we identified the Triquetrorhabdulus cf. challengeri taxon and introduced it as a bio-event. The LO of T. cf challengeri lies in the lower part of Zone NN1 in all sections (Figs. 4-6 and Table 1). The species is rare and sporadic in Zone NN1 and becomes more abundant in the Miocene succession.

G: HO of Helicosphaera recta. This is an important bio-event observed in the middle part of Zone NN1 and it has been used to define the Oligocene-Miocene boundary by some scientists (Martnini, 1971; Perch-Nielsen, 1985), while other researchers (e.g., Rio et al., 1990; Raffi et al., 2006; Backman et al., 2012) reported its LO already within the Oligocene. We also consistently observed the $\mathrm{HO}$ of $H$. recta within the Oligocene assemblages in our material. The abundance patterns of this taxon in 


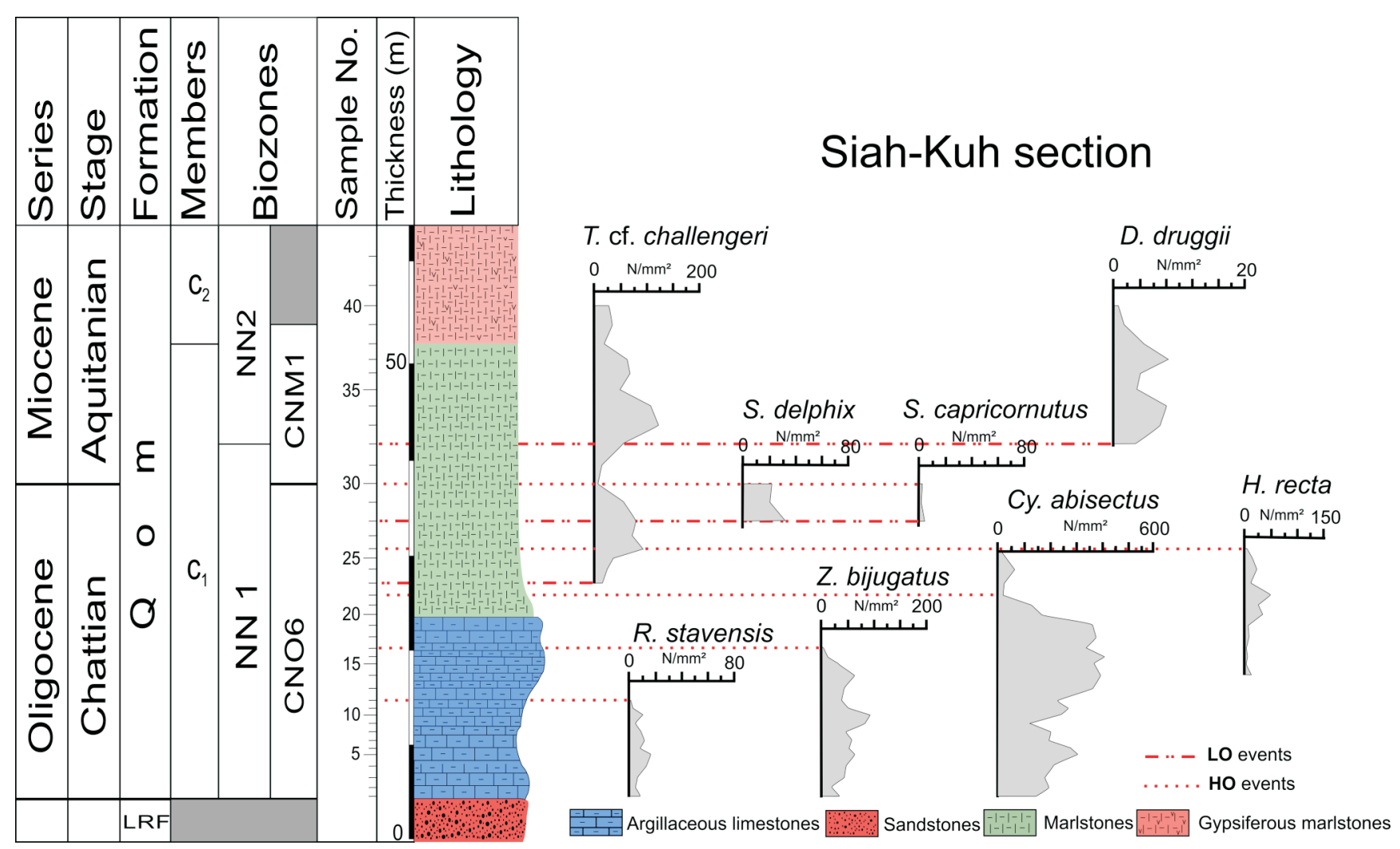

Fig. 6. Abundance patterns of marker calcareous nannofossil species from the Oligocene/Miocene interval of the Siah-Kuh section shown against the zonal schemes of Martini (1971; NP and NN), Agnini et al. (2014; CNO) and Backman et al. (2012; CNM); the X-axis values represent the number of specimens in a prefixed area $\left(\mathrm{N} / \mathrm{mm}^{2}\right)$ related to $50 \mathrm{FOV}$; dashed lines highlight the LO or $\mathrm{HO}$ of species; the light grey rectangles show unstudied intervals

our sections are shown in Figures 4-6 and the stratigraphic positions of its $\mathrm{HO}$ are recorded in Table 1 for each section.

H: LO of Sphenolithus delphix. Literature data places the LO of S. delphix below magnetozone C6Cn.2n (Rio et al., 1990; Fornaciari and Rio, 1996; Steininger et al., 1997; Shackleton et al., 2000; Raffi et al., 2006; Backman et al., 2012; Agnini et al., 2014; Albasrawi, 2016). In the studied sections and in agreement with previous results, this bio-event is observed in the upper part of Zone NN1 and before the first appearance of Miocene species (Figs. 4-7 and Table 1).

I: LO of Sphenolithus capricornutus. The LO of S. capricornutus was reported in the GSSP of the Paleogene-Neogene boundary by Steininger et al. (1997). According to the phylogenic chart by Perch-Nielsen (1985), S. capricornutus is the youngest of all Paleogene species. Herein, the LO of $S$. capricornutus occurs in the Upper Oligocene nannofossil assemblages and within the upper part of Zone NN1. The distribution patterns and the position of the LO in the three sections are shown in Figures 4-6 and Table 1.

J: HO of Sphenolithus delphix and S. capricornutus. These bio-events (HOs of S. delphix and S. capricornutus) are recorded in the upper part of the Sub-member "c1", at the top of the Oligocene calcareous nannofossil assemblages and/or strata (Figs. 4-7 and Table 1). Just above these events, the index calcareous nannofossil assemblages of the Miocene are present, including S. tintinnabulum, Reticulofenestra haqii, Hughesius gizoensis, $H$. youngii and $H$. carteri. Previously, the $\mathrm{HO}$ of S. delphix was used to define the zonal boundary of Zone CNO6 by Agnini et al. (2014), and Zone CNM1 by Backman et al. (2012) in the Paleogene and Neogene strata, respectively. According to these studies, the $\mathrm{HO}$ of $\mathrm{S}$. delphix is recorded close to the Oligocene-Miocene boundary.

K: LO of Discoaster druggii. The LO of $D$. druggii occurs above the HOs of the Late Oligocene index species in the studied sections (Figs. 4-6 and Table 1), which is in agreement with other studies. Martini (1971), Okada and Bukry (1980) and Perch-Nielsen (1985) used this bio-event to define Zones NN1 and CN1b/c. Backman et al. (2012) used the LO of Sphenolithus disbelemnos to determine the CNM1/CNM2 zonal boundary which lies at a stratigraphic level younger than the LO of $D$. druggii. Backman et al. (2012) reported the D. druggii biohorizon in the upper part of Zone CNM1 and at the base of the Aquitanian succession at low to middle latitude sites (Fig. 7). In the present study, the LO of $D$. druggii is recorded from the upper part of Zone NN1 (Fig. 7). The S. disbelemnos was not recorded among the calcareous nannofossil assemblages in Sub-member "c1" (Figs. 4-6).

\section{DISCUSSION}

The calcareous nannofossil markers used for the identification of the Oligocene-Miocene boundary have changed over time. According to the standard zonation of Martini (1971) and definition of Zone NN1, the boundary has been placed at the $\mathrm{HO}$ of either Helicosphaera recta or Sphenolithus ciperoensis (Fig. 7). Okada and Bukry (1980) have used the HOs of S. 


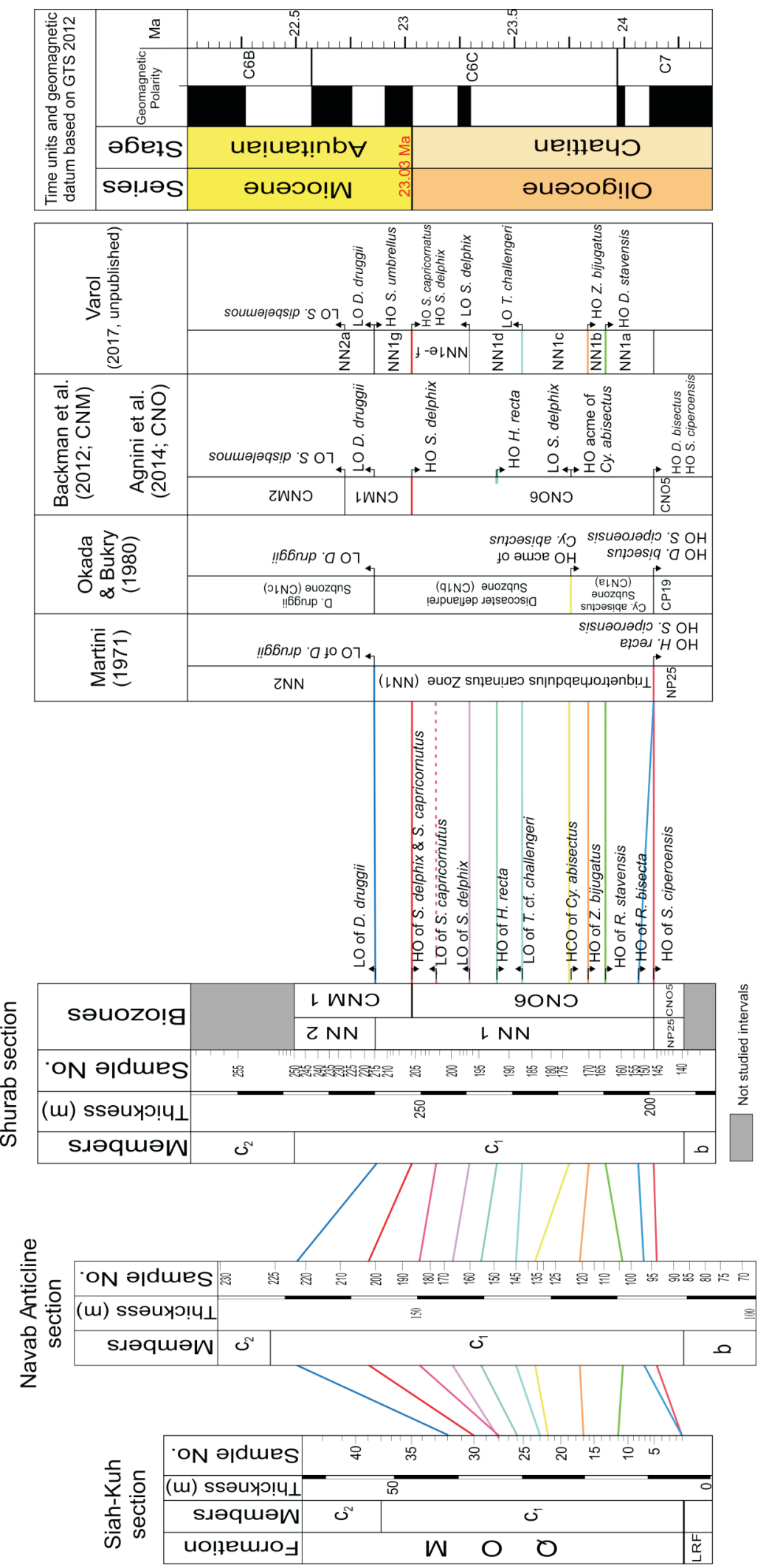



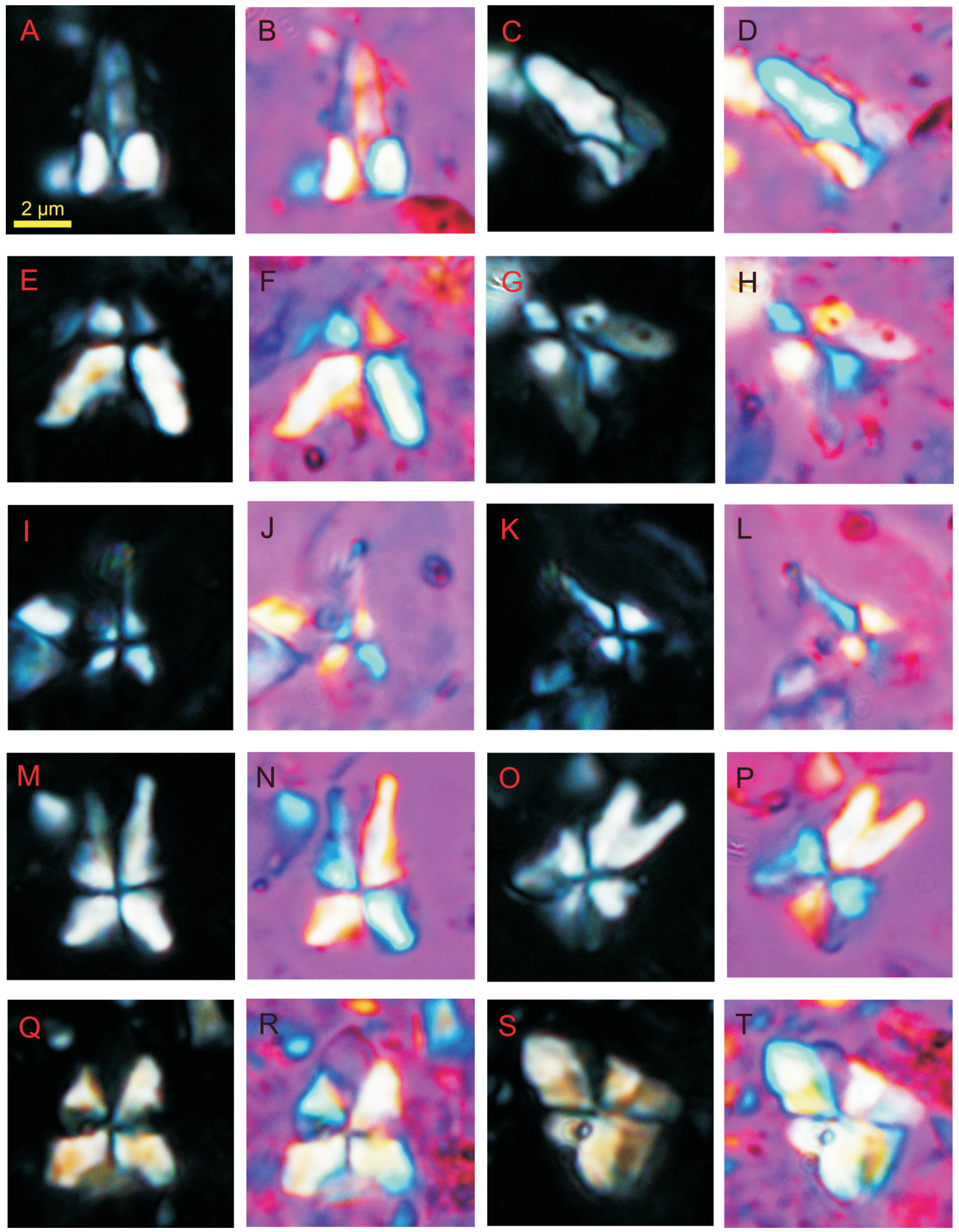

Fig. 8. Index and commonly recorded calcareous nannofossils from the studied sections

A-D - Sphenolithus ciperoensis Bramlette and Wilcoxon, 1967 (A, C - XPL; B, D - GP; A, B - 0 ; C, D - 45 ); E-H - Sphenolithus delphix

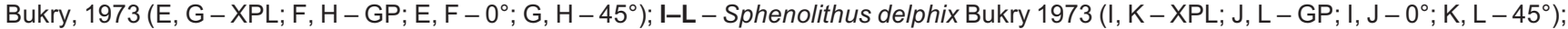
M-P - Sphenolithus capricornutus Bukry and Percival, 1971 (M, O - XPL; N, P - GP; M, N - 0 ; O, P - 45 ); Q-T - Sphenolithus conicus Bukry, $1971\left(\mathrm{Q}, \mathrm{S}-\mathrm{XPL} ; \mathrm{R}, \mathrm{T}-\mathrm{GP} ; \mathrm{Q}, \mathrm{R}-0^{\circ} ; \mathrm{S}, \mathrm{T}-45^{\circ}\right)$; scale bar is $2 \mu \mathrm{m}$ in all images 

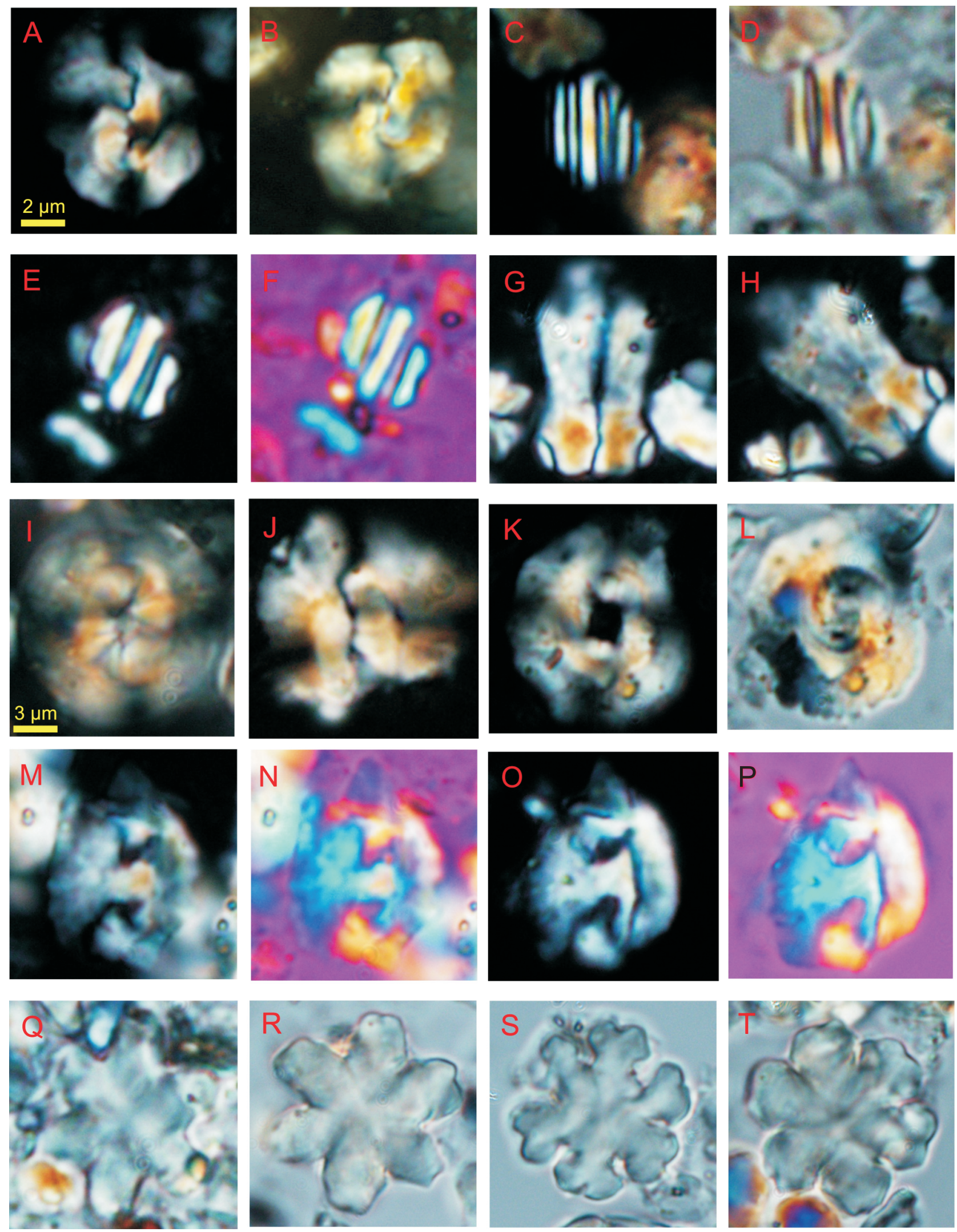

Fig. 9. Index and common calcareous nannofossils from the studied sections

A, B - Reticulofenestra bisecta (Hay, Mohler and Wade, 1966) Roth, 1970 (A, B - XPL); C, D - Triquetrorhabdulus cf. challenger Perch-Nielsen, 1977 (C - XPL; D - QP); E, F - Triquetrorhabdulus cf. challengeri Perch-Nielsen, 1977 (E - XPL; F - GP; E, F - 45ํ); G, H Zygrhablithus bijugatus Deflandre, 1959 (G, H-XPL; G - 0 ; H - 45 ); I, J-Reticulofenestra stavensis (Levin and Joerger, 1967) Varol, 1989 (I, J-XPL); K, L - Cyclicargolithus abisectus (Muller, 1970) Wise, 1973 (K-XPL; L - QP); M, N - Helicosphaera recta (Haq, 1966) Jafar and Martini, 1975 (M - XPL; N - GP); O, P - Helicosphaera recta (Haq, 1966) Jafar and Martini, 1975 (O - XPL; P - GP); Q, R - Discoaster druggii Bramlette and Wilcoxon, 1967 (Q, R - QP); S, T - Discoaster deflandrei Bramlette and Riedel, 1954 (S, T - QP); scale bar is $2 \mu \mathrm{m}$ in images of $\mathrm{A}$ to $\mathrm{H}$, and $3 \mu \mathrm{m}$ in I to $\mathrm{T}$ 
Biohorizons identified in the Oligocene-Miocene transition

\begin{tabular}{|l|c|c|c|}
\multicolumn{1}{|c|}{ Sections } & Shurab & $\begin{array}{c}\text { Navab } \\
\text { Bnticline }\end{array}$ & Siah-Kuh \\
\hline \multicolumn{1}{|c|}{ Bio-Events } & \multicolumn{2}{c|}{ Thickness [m] } \\
\hline FO of Discoaster druggii & 259.6 & 168 & 42 \\
\hline LO of Sphenolithus delphix and S. capricornutus & 252 & 158 & 38 \\
\hline FO of Sphenolithus capricornutus & 245 & 149 & 34 \\
\hline FO of Sphenolithus delphix & 238.6 & 145.3 & 34 \\
\hline LO of Helicosphaera recta & 234 & 141 & 31 \\
\hline FO of Triquetrorhabdulus cf. challengeri & 227 & 135.9 & 27 \\
\hline LCO of Cyclicargolithus abisectus & 217 & 133 & 26 \\
\hline LO of Zygrhablithus bijugatus & 213 & 126 & 20 \\
\hline LO of Reticulofenestra stavensis & 209 & 119 & 15 \\
\hline LO of Reticulofenestra bisecta & 203 & 117 & - \\
\hline LO of Sphenolithus ciperoensis & 198 & 114 & - \\
\hline
\end{tabular}

The stratigraphic position of the bio-events is reported from the base of the sections

ciperoensis and Reticulofenestra bisecta, and the end of the acme interval of Cyclicargolithus abisectus to define subzone $\mathrm{CN} 1 \mathrm{a}$, with the latter event and the first occurrence of Discoaster druggii to define subzone CN1b (Fig. 7). Rio et al. (1990), Backman et al. (2012) and Agnini et al. (2014) have postulated that the $S$. ciperoensis, $H$. recta, $D$. druggii, $T$. carinatus, $R$. bisecta and $C$. abisectus events exhibit uncertain distribution patterns (see Fig. 10). Therefore, biohorizons and defined biozones across the Oligocene-Miocene boundary are considered to be of limited value (Rio et al., 1990; Backman et al., 2012; Agnini et al., 2014). The oldest event is the HO of S. ciperoensis at the lower boundary of Zone NN1 (or CN1a), followed by the $\mathrm{HO}$ of $R$. bisecta, the top of the acme zone of $C$. abisectus, the LO of S. delphix, the $\mathrm{HO}$ of $\mathrm{H}$. recta, and finally the HO of S. delphix, all within Zone NN1 (Agnini et al., 2014) (Fig. 7).

Martini (1971) and Perch-Nielsen (1985) thought that the NP25/NN1 zonal boundary was correlative to the Paleogene and Neogene system boundary and defined to the $\mathrm{HO}$ of $\mathrm{S}$. ciperoensis and/or the $\mathrm{HO}$ of $H$. recta species. Rio et al. (1990) confirmed the earlier finding that, in fact, these events occur below the base of the Neogene in its type area. They have reported the bio-events younger than the HOs of S. ciperoensis and $H$. recta, which include the LOs and then the LOs of $S$. delphix and S. capricornutus. Steininger et al. (1997) have published the position of the aforementioned bio-events (FOs and LOs of S. delphix and S. capricornutus) in the GSSP study of the base of the Neogene (Aquitanian stage). In addition, Ogg et al. (2016) have applied these biohorizons to define the Chattian/Aquitanian stage boundary (corresponding to the base of magnetic polarity chron C6Cn.2n). Lourens et al. (2004) and Palike et al. (2006) have determined an age of $23.03 \mathrm{Ma}$ for the base of this magnetochrone (C6Cn.2n) at the base of the Aquitanian. Therefore, the LO of $S$. delphix is the nearest bio-event to the Oligocene-Miocene boundary and provides a distinct horizon occurring prior to the boundary (see Agnini et al., 2014; Fig. 7). Furthermore, there are many publications from the various sites, which uniformly show that the FO of $D$. druggii is in the Early Miocene (e.g., Martini, 1971; Perch-Niel- sen, 1985; Rio et al., 1990; Fornaciari et al., 1990; Raffi et al., 2006; Backman et al., 2012). In the high latitude areas, the mentioned bio-events are different from those of low to middle latitudes (Perch-Nielsen, 1985).

A review of current literature clearly shows that the bioevents used for the definition of biozonal boundaries in low latitude areas of the Tethys region can hardly be recognized in the central Paratethys, and/or when present they are recorded in the younger horizons (Fig. 10; see Holcova, 2005; Ozdinova and Sotak, 2014; Grunert et al., 2015). Generally, the Paratethys domain, as a chain-restricted basin, is marked by poor to moderate preservation of nannofossils, rare or scant occurrences of their assemblages, and inappropriate environmental conditions (Holcova, 2005; Grunert et al., 2015). Due to these restrictions, comparison of the Paratethys and Tethys regions is complicated and imposes many uncertainties.

As shown in Figure 10, some bio-events (e.g., H. recta and $R$. bisecta) are recorded in different biostratigraphic ranges within the Paratethys realm, and/or absent (such as S. delphix, $S$. capricornutus, $T$. challengeri). Therefore, the bio-events of the Paratethys are not exactly correlatable with the bio-events in the Tethyan region (Fig. 10).

Eleven biohorizons have been determined between the LO of $S$. ciperoensis and the FO of $D$. druggii, providing a biostratigraphic framework and improving resolution for defining the Oligocene-Miocene boundary. The distinguished bioevents are in agreement with other studied sites in the low and middle latitudes, and consist of the above-described LOs and FOs within Zone NN1 of Martini (1971). The HO of S. delphix is the latest recorded bio-event within the Oligocene calcareous nannofossil assemblage in the studied sections of the Qom Formation (Figs. 4-6). Following this bio-event, the first appearance of $D$. druggii is the lowest determinable biohorizon within the Neogene nannofossil assemblages which is observed in the thickness of $259.6 \mathrm{~m}$ Shurab, $168 \mathrm{~m}$ in the Navab Anticline and $42 \mathrm{~m}$ in the Siah-Kuh sections.

Reuter et al. (2007) previously placed the Oligocene-Miocene boundary within the C-Member of the Qom Formation. This member includes a thickened interval of strata (Qom For- 

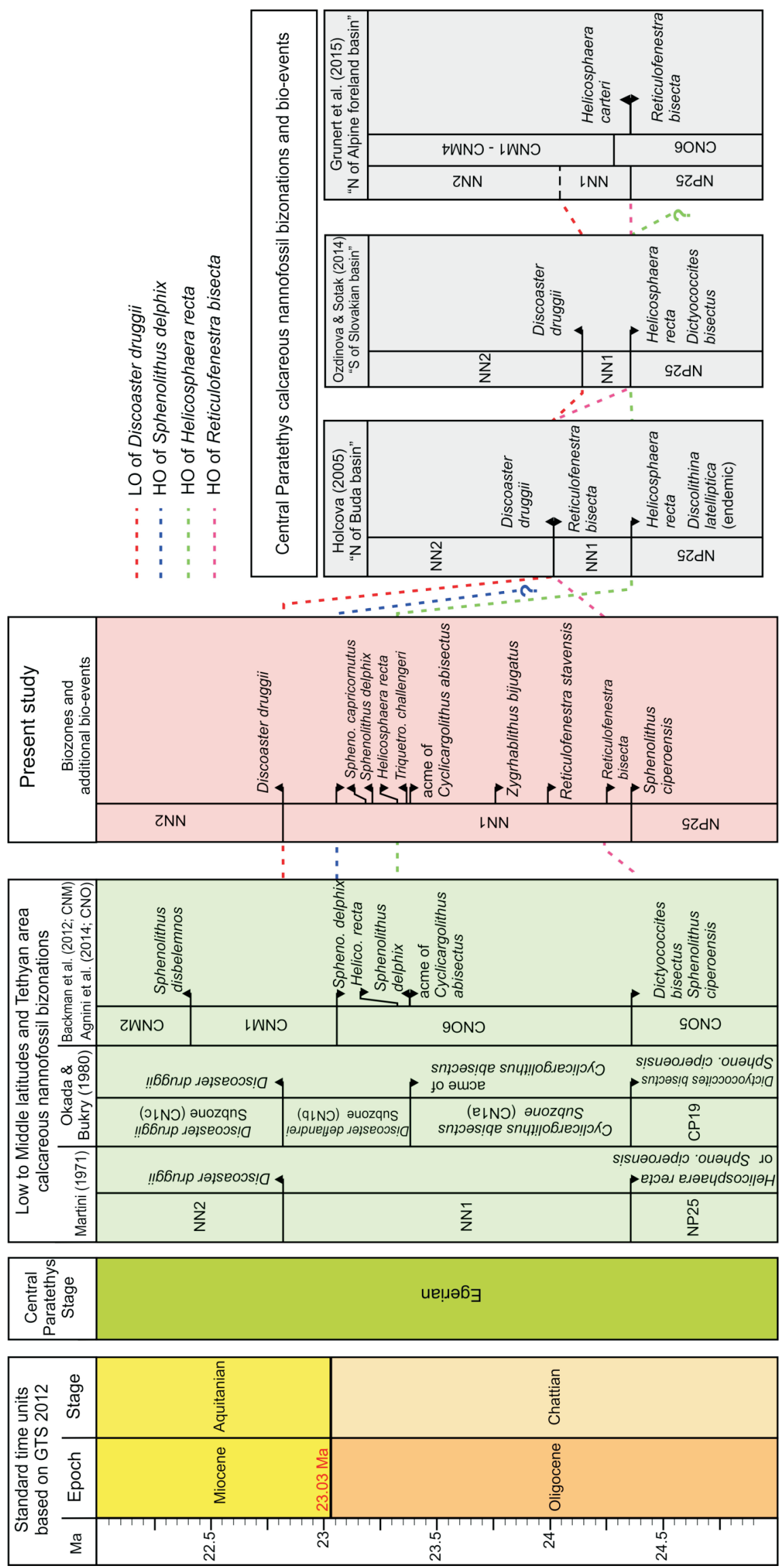
mation) and it is not exactly suitable for regional correlation. The definition of the boundary based on calcareous nannofossil events within the upper part of Sub-member "c1" in this study provides a better and more detailed litho-biostratigraphic framework for correlation.

\section{CONCLUSIONS}

Detailed analysis of calcareous nannofossil assemblages led for the first time to the identification of useful calcareous nannofossil biohorizons around the Oligocene-Miocene boundary in the Qom Basin. The determined bio-events located in the standard biozone NN1 of Martini (1971), which spans the Upper Oligocene-Lower Miocene. The zone/bio-events are correlative with the occurrences reported from low to middle latitude sites by Backman et al. (2012), Agnini et al. (2014) and Varol (2017). Among the described biohorizons, the $\mathrm{HO}$ of S. delphix is a useful marker for the identification and tracking of the Oligocene-Miocene boundary that is placed in the upper part of Sub- -member "c1" of the Qom Formation. Considering the large regional extent of Sub-member "c1" in the Qom Basin, the boundary is traceable over a wide geographical area in the Tethyan realm. Therefore, the $\mathrm{HO}$ of $S$. delphix can be regarded as a trusted biostratigraphic marker for sequence stratigraphic and hydrocarbon exploration studies.

Acknowledgements. The authors would like to thank Prof. M. Pierre Aubry (University of Rutgers, USA) for her advices, editing the English text, and checking the determinations of calcareous nannofossils. We are also grateful to Prof. J. Young (University College of London, UK) for interesting talks about the calcareous nannofossil taxa. We would like to acknowledge the Exploration Directorate of NIOC (National Iranian Oil Company) for providing laboratorial facilities. This paper is a part of a research project (No. 3/39428) granted by the Ferdowsi University of Mashhad. The authors greatly appreciate the reviewers: G. Auer and an anonymous one for their reviews, which significantly improved the manuscript. Many thanks go to T.M. Peryt and W. Granoszewski (editor) and reviewer (G. Auer) for the manuscript editing.

\section{REFERENCES}

Abaie, I., Ansari, H.J., Badakhshan, A., Jafari, A., 1964. History and development of the Alborz and Sarajeh fields of Central Iran. Bulletin of Iranian Petroleum Institute, 15: 561-574.

Aghanabati, A., 2004. Geology of Iran. Geological Survey of Iran, Tehran, Iran, 586

Agnini, C., Fornaciari, E., Raffi, I., Catanzariti, R., Pälike, H., Backman, J., Rio, D., 2014. Biozonation and biochronology of Paleogene calcareous nannofossils from low and middle latitudes. Newsletters on Stratigraphy, 47: 131-181.

Albasrawi, W.A., 2016. Early Miocene Quantitative Calcareous Nannofossil Biostratigraphy from the Tropical Atlantic. Dissertations and Theses in Earth and Atmospheric Sciences, University of Nebraska: $1-7$.

Allen, M.B., Armstrong, H.A., 2008. Arabia-Eurasia collision and the forcing of mid Cenozoic global cooling. Paleogeography, Palaeoclimatology, Palaeoecology, 265: 1-30.

Aubry, M.P., 1984. Handbook of Cenozoic Calcareous Nannoplankton, 1: Ortholithae (Discoasters). Micropaleontology Press, New York.

Aubry, M.P., 1988. Handbook of Cenozoic Calcareous Nannoplankton, 2: Ortholithae (Holococcoliths, Ceratoliths, Ortholiths and others). Micropaleontology Press, New York.

Aubry, M.P., 1989. Handbook of Cenozoic Calcareous Nannoplankton, 3: Ortholithae (Pentaliths, and others), Heliolithae (Fasciculiths, Sphenoliths and others). Micropaleontology Press, New York.

Aubry, M.P., 1990. Handbook of Cenozoic Calcareous Nannoplankton, 4: Heliolithae (Helicoliths, Cribriliths, Lopadoliths and others). Micropaleontology Press, New York, 381.

Aubry, M.P., 2016. Cenozoic chronostratigraphic terminology: in defense of formal subseries. Stratigraphy, 13: 1-20.

Backman, J., Shackleton, N.J., 1983. Quantitative biochronology of Pliocene and early Pleistocene calcareous nannoplankton from the Atlantic, Indian and Pacific Oceans. Marine Micropaleontology, 8: 141-170.

Backman, J., Raffi, I., Rio, D., Fornaciari, E., Palike, H., 2012. Biozonation and biochronogy of Miocene through Pleistocene calcareous nannofossils from low and middle latitudes. Newsletters on stratigraphy, 45: 221-244.
Beddow, H.M., Liebrand, D., Sluijs, A., Wade, B.S., Lourens, L.J., 2016. Global change across the Oligocene-Miocene transition: high-resolution stable isotope records from IODP Site U1334 (equatorial Pacific Ocean). Paleoceanography, 31: 81-97.

Berberian, M., King, G.C.P., 1981. Towards a paleogeography and tectonic evolution of Iran. Canadian Journal of Earth Sciences, 18: 210-265.

Berggren, W.A., 1969. Cenozoic chronostratigraphy, planktonic foraminiferal zonation and the radiometric time scale. Nature, 224: 1072-1075.

Berggren, W.A., Kent, D.V., Van Couvering, J.A., 1985. The Neogene: Part 2, Neogene geochronology and chronostratigraphy. Geological Society Memoir, 10: 211-260.

Billups, K., Channell, J.E.T., Zachos, J., 2002. Late Oligocene to early Miocene geochronology and paleoceanography from the subantarctic South Atlantic. Paleoceanography, 17: 1-11.

Bown, P.R., Young, J.R., 1998. Techniques. In: Calcareous Nannofossil Biostratigraphy (ed. P.R. Bown): 16-28. Chapman and Hall, London.

Bozorgnia, F., 1966. Qum Formation stratigraphy of the Central Basin of Iran and its intercontinental position. Bulletin of the Iranian Petroleum Institute, 24: 69-75.

Catuneanu, O., 2013. Principles of Sequence Stratigraphy. Science and Technology, Elsevier.

Daneshian, J., Ghanbari, M., 2017. Stratigraphic distribution of planktonic foraminifera from the Qom Formation: a case study from the Zanjan area (NW Central Iran). Neues Jahrbuch für Geologie und Paläontologie, 283: 239-254.

Daneshian, J., Ramezani Dana, L.R., 2007. Early Miocene benthic foraminifera and biostratigraphy of the Qom Formation, Deh Namak, central Iran. Journal of Asian Earth Sciences, 29: 844-858.

Daneshian, J., Ramezani Dana, L.R., 2017. Foraminiferal biostratigraphy of the Miocene Qom Formation, northwest of the Qom, Central Iran. Frontiers of Earth Science, 12: 1-15.

Dozy, J., 1944. Comments on geological report No. 1, by Thiebaud (on Qum - Saveh area). Geological report no. 308.

Dozy, J., 1955. A sketch of post-Cretaceous volcanism in central Iran. Leidsche Geologische Mededelingen, 20: 48-57. 
Emami, M.H., 1992. Geological map of 1:250 000 Aran area. Geological Survey of Iran.

Farinacci, A., 1989. Catalogue of Calcareous Nannofossils. Edizioni tecnoscienza, Roma, Volumes: 1-13.

Furrer, M.A., Soder, P.A., 1955. The Oligo-Miocene marine formation in the Qum region (Central Iran). Rome, Italy. In: Proceedings of the 4th World Petroleum Congress, Rome: 267-277.

Fornaciari, E., Rio, D., 1996. Latest Oligocene to early middle Miocene quantitative calcareous nannofossil biostratigraphy in the Mediterranean region. Micropaleontology, 1: 1-36.

Fornaciari, E., Raffi, I., Rio, D., Villa, G., Backman, J., Olafsson, G., 1990. Quantitative distribution patterns of Oligocene and Miocene calcareous nannofossils from the western equatorial Indian Ocean. Proceeding of the ODP, Scientific Results, College Station, TX (Ocean Drilling Program), 115: 237-254.

Gradstein, F.M., Ogg, J.G., Schmitz, M.D., Ogg, G.M., 2012. The Geologic Time Scale (GTS) 2012. Elsevier, 2: 855-978.

Grunert, P., Auer, G., Harzhauser, M., Piller, W., 2015. Stratigraphic constraints for the upper Oligocene to lower Miocene Puchkirchen Group (North Alpine Foreland Basin, Central Paratethys). Newsletters on Stratigraphy, 48: 111-133.

Hadavi, F., Notghi-Moghaddam, M., Mousazadeh, H., 2010. Burdigalian-Serravalian calcareous nannoplanktons from Qom Formation, northcenter Iran. Arabian Journal of Geosciences, 3: 133-139.

Holcova, K., 2005. Quantitative calcareous nannoplankton biostratigraphy of the Oligocene/Miocene boundary interval in the northern part of the Buda Basin (Central Paratethys). Geological Quarterly, 49 (3): 260-274.

Howe, R., 2016. Updating the Catalog of Calcareous Nannofossils, expansion and renaming, Nannotax website (www.mikrotax.org).

Khalatbari, M., Alavi, S., 1996. Geological map of 1:100 000 Natanz area. Geological Survey of Iran.

Lourens, L.J., Hilgen, F.J., Shackleton, N.J., Laskar, J., Wilson, D., 2004. The Neogene Period. In: A Geological Time Scale 2004 (eds. F.M. Gradstein, J.G. Ogg and A.G. Smith): 409-440. Cambridge University Press, Cambridge.

Martini, E., 1971. Standard Tertiary and Quaternary Calcareous nannoplankton zonation. Proceedings II Planktonic Conference, Roma, 1: 739-785

Miller, K.G., Wright, J.D., Fairbanks, R.G., 1991. Unlocking the Ice House: Oligocene-Miocene oxygen isotopes, eustasy, and margin erosion. Journal of Geophysical research, 96: 6829-6848.

Mohammadi, E., Safari, A., Vaziri-Moghaddam, H., Vaziri, M.R., Ghaedi, M., 2011. Microfacies analysis and paleoenviornmental interpretation of the Qom Formation, south of the Kashan, central Iran. Carbonates and Evaporites, 26: 255-271.

Mohammadi, E., Hasanzadeh-Dastgerdi, M., Ghaedi, M., Dehghan, R., Safari, A., Vaziri Moghaddam, H., Baizidi, C., Vaziri, M., Sfidari, E., 2013. The Tethyan Seaway Iranian Plate Oligo-Miocene deposits (the Qom Formation): distribution of Rupelian (Early Oligocene) and evaporate deposits as evidences for timing and trending of opening and closure of the Tethyan Seaway. Carbonates and Evaporites, 28: 321-345.

Mostofi, R., Gansser, A., 1957. The story behind the 5 Alborz. Oil Gas Journal, 55: 78-84.

Okada, H., Bukry, D., 1980. Supplementary modification and introduction of code numbers to the low-latitude coccolith biostratigraphic zonation (Bukry, 1973; 1975). Marine Micropaleontology, 5: 321-325.

Ogg, J.G., Ogg, G.M., Gradstein, F., 2016. A Concise Geologic Time Scale (GTS). Elsevier: 187-210.

Olafsson, G., 1992. Oligocene-Miocene morphometric variability of the Cyclicargolithus group from the equatorial Atlantic and Indian Oceans. Memorie di Scienze Geologiche, 43: 283-296.

Ozdinova, S., Sotak, J., 2014. Oligocene-Early Miocene planktonic microbiostratigraphy and paleoenvironments of the South Slovakian Basin (Lučenec Depression). Geologica Carpathica, 65: $451-470$
Pagani, M., Arthur, M., Freeman, K.H., 1999. Miocene evolution of atmospheric carbon dioxide. Paleoceanography, 14: 273-292.

Pekar, S.F., Kominz, M.A., Miller, K.G., 2002. Calibration between eustatic estimates from backstripping and oxygen isotopic records for the Oligocene. Geology, 30: 903-906.

Palike, H., Norris, R.D., Herrle, J.O., Wilson, P.A., Coxall, H.K., Lear, C.H., Shackleton, N.J., Tripati, A.K., Wade, B.S., 2006. The heartbeat of the Oligocene climate system. Science, 14: 1894-1898.

Parandavar, M., 2018. Investigation of Qom Formation on the basis of calcareous nannofossil in the Shurab, Navab anticline and Siah-Kuh sections (Qom basin), Ph.D. thesis, Ferdowsi University of Mashhad.

Parandavar, M., Hadavi, F., 2017. Calcareous nannofossils biostratigraphy of the Qom Formation in Central Iran. 16th International Nannoplankton Association (INA) conference, Athens, 79.

Pearson, P., Palmer, M., 2000. Atmospheric carbon dioxide concentrations over the past 60 million years. Nature, 406: 695-699.

Perch-Nielsen, K., 1985. Cenozoic calcareous nannofossils In: Plankton Stratigraphy (eds. H.M. Bolli, J.B. Sunders, K. Perch-Nielsen): 329-554. Cambridge Earth Science Series, New York.

Raffi, I., Backman, J., Fornaciari, E., Pälike, H., Rio, D., Lourens, L., Hilgen, F., 2006. A review of calcareous nannofossil astrobiochronology encompassing the past 25 million years. Quaternary Science Reviews, 25: 3113-3137.

Rahaghi, A., 1973. Étude de quelques grands foraminifères de la Formation de Qum (Iran Central). Revue de Micropaléontologie, 16: $23-38$.

Rahaghi, A., 1976. Contribution a l'étude de quelques grands foramifères de l'Iran. Société National Iranienne des Pétroles Laboratoire de Micropaléontologie. Publication no. 6, Parts 1-3: 1-79.

Rahaghi, A., 1980. Tertiary Faunal Assemblage of Qum-Kashan, Sabzewar and Jahrum Areas. National Iranian Oil Company, Geological Laboratories, Publication no. 8: 1-64.

Reuter, M., Piller, W.E., Harzhauser, M., Mandic, O., Berning, B., Rögl, F., Kroh, A., Aubry, M.P., Wielandt-Schuster, U., Hamedani, A., 2007. The Oligo-Miocene Qom Formation (Iran): evidence for an early Burdigalian restriction of the Tethyan seaway and closure of its Iranian gateway. International Journal of Earth Sciences, 98: 627-650.

Rio, D., Fornaciari, E., Raffi, I., 1990. Late Oligocene through early Pleistocene calcareous nannofossils from western equatorial Indian Ocean (Leg 115). Proceeding of the ODP, Scientific Results, College Station, TX (Ocean Drilling Program), 115: 175-235.

Rosenberg, R., 1975. Qum-1956: a misadventure in Iranian Oil. Business Historical Revision, 49: 81-104.

Sadr, F.D., 2017. Evolution of the Tethyan seaway during the Oligocene-Miocene: constraints from foraminiferal faunas of the Qom Formation, Iran. Ph.D. thesis, University of Hamburg.

Shackleton, N.J., Hall, M.A., Raffi, I., Tauxe, L., Zachos, J., 2000. Astronomical calibration age for the Oligocene-Miocene boundary. Geology, 28: 447-450.

Shahabpour, J., 2007. Island-arc affinity of the Central Iranian Volcanic Belt. Journal of Asian Earth Sciences, 30: 652-665.

Soder, P.A., 1956. Detailed investigations on the marine formation of Qum. Exploration Directorate of NIOC, Geological report no. 154: $1-23$

Soder, P.A., 1959. Detailed investigations on the marine formation (Oligo-Miocene) of Qum. Geological report No. 186 of Exploration Directorate, NIOC

Steininger, F.F., Aubry, M.P., Berggren, W.A., Biolzi, M., Borsetti, A.M., Cartlidge, J.E., Cati, R., Corfield, R., Gelati, R., lacarino, S., Napoleone, C., Ottner, E., Rögl, F., Roetzel, R., Spezzaferri, S., Tateo, F., Villa, G., Zevenboom, D., 1997. The global stratotype section and point (GSSP) for the base of the Neogene. Episodes, 20: 23-28. 
Stoecklin, J., 1959. A section through the Oligocene-Miocene Marine Formation south of Shurab R.S. initial report of Iranian Oil Company, Geological note no. 49: 1-17.

Stocklin, J., Setudehnia, A., 1991. Stratigraphic Lexicon of Iran. Geology Survey of Iran. Report no. 18: 1-376.

Varol, O., 1998. Paleogene calcareous nannofossil biostratigraphy. In: Calcareous Nannofossil Biostratigraphy (ed. P.R. Bown): 200-224. Kluwer Academic Publishers.

Varol, O., 2017. Global Nannofossil Events of the Oligocene-Miocene Boundary. Varol research biostratigraphic company (www.varol.com), Houston, USA.
Wade, B.S., Palike, H., 2004. Oligocene climate dynamics. Paleoceanography, 19 (4019): 1-16.

Yazdi-Moghadam, M., 2011. Early Oligocene larger foraminiferal biostratigraphy of the Qom Formation, South of Uromieh (NW Iran). Turkish Journal of Earth Science, 20: 847-856.

Young, J.R., 1998. Neogene calcareous nannofossil biostratigraphy. In: Calcareous Nannofossil Biostratigraphy (ed. P.R. Bown): 225-265. Kluwer Academic Publishers.

Zachos, J.C., Pagani, M., Sloan, L., Thomas, E., Billups, K., 2001. Trends, Rhythms, and Aberrations in Global Climate 65 Ma to Present. Science, 292: 686-694. 